\title{
The Causal Linkage Between Agriculture, Industry and Service Sectors in Ethiopian Economy
}

\author{
Adisu Abebaw Degu \\ Department of Economics, Salale University, Fiche, Ethiopia \\ Email address: \\ adisuaad@gmail.com \\ To cite this article: \\ Adisu Abebaw Degu. The Causal Linkage Between Agriculture, Industry and Service Sectors in Ethiopian Economy. American Journal of \\ Theoretical and Applied Business. Vol. 5, No. 3, 2019, pp. 59-76. doi: 10.11648/j.ajtab.20190503.13
}

Received: July 8, 2019; Accepted: August 4, 2019; Published: October 10, 2019

\begin{abstract}
Investigation of structural relationships among the sectors becomes important from the policy angle. A clear perspective on the intersectoral linkage could be useful in formulating a favorable and appropriate development strategy. This study analyzed the intersectoral linkages in Ethiopian economy using a time series data ranging from 1975 to 2017 . The study employed Johanson co-integration test, vector error correction model, granger causality test, impulse response and variance decomposition functions. The study found a stable long run relationship among agricultural, industrial and service sectors of the economy. Only industrial sector is found as endogenous to the system implying long-run causality runs form agricultural and service sectors to industrial sector. According to short run granger causality results, there is bi-directional causality between industrial and agricultural sectors, and between industrial and service sectors. The results of Impulse response and Variance decomposition functions suggest that the agricultural sector development plays a role in determining the growth of the economy via its linkages to the rest sectors of the economy. Therefore, development strategies such as, Agricultural Development Led Industrialization (ADLI) of Ethiopia, if properly implemented can play an encouraging role by reassuring the agricultural sector, so that the industrial sector would be promoted. In addition the percentage share of agricultural sector to GDP has been declining over the study period. However, this doesn't indicate that the role of agricultural sector is falling. The analysis of intersectoral linkages identified agricultural sector as the principal economic activity that controls most economic activities in Ethiopian economy.
\end{abstract}

Keywords: Cointegration, Granger Causality, Endogenous, Impulse Response, Variance Decomposition, ADLI

\section{Introduction}

\subsection{Background}

The structural changes of an economy entail that in the long run, the dynamics of sectoral shares are interrelated to each other and with economic growth [33]. Economic development and structural changes are known to go hand-inhand. If faced with distortionary policies, an economy might, however, witness such temporal changes in the composition of different sectors and sub-sectors in productivity and employment level which could lead to unbalanced growth within sectors [46].

Agricultural and industrial sectors have a mutual interdependent relationship [31]. However, whether agriculture or industry should be considered as the main stimuli of growth and how the service sector should be linked up with the two sectors have been debatable issues [3], especially at early stage of economic development. It is argued that Industrialization has a number of roles to play in the process of economic development. this role can be in the form of providing employment opportunities to the agricultural sector, supplying agricultural inputs such as; pesticides, fertilizer and different machineries which augment productivity in the agricultural [31] and it brings increasing returns and economies of scale while agriculture does not give such gains [17].

Another argument emphasizes on the significance agricultural sector at least at the initial stage of economic development. The contribution of agriculture sector to industry is well known, particularly in less developed countries [31]. The argument follows that Agricultural sector provides; food grains to industry to facilitate absorption of labor in the industrial sector and industrial raw materials, it 
influences the production of industrial consumer goods through demand and provides surpluses of savings for investment in the industrial sector [17-31].

Since the economies of most developing countries are dominated by the agricultural sector and its activities, and the modern industrial sector is subordinate, the economic growth and the development of these countries are closely related with the transformation of the agricultural sector [37]. Agriculture sector in Ethiopian economy covers 35.8 percent of GDP while the industrial and service sectors cover 22.2 and 42 percent of GDP respectively. However, more than $70 \%$ of Ethiopia's population is still engaged in agricultural sector, but services have exceeded agricultural sector in terms of contribution to GDP [47]. The government of Ethiopia has been implementing the overall development strategy of Ethiopia is Agricultural Development Led Industrialization (ADLI). Its major objective is to strengthen the linkage between agricultural and industrial sectors; growth in agriculture is supposed to bring the overall growth via stimulating both demand and supply linkages [8 - 29].

The concept of sectoral linkage which was developed from the theory of 'unbalanced growth' of Hirschman, converses the relationship a sector with the rest of the economy through its direct and indirect intermediate purchases and sales [9]. The sectors having the highest linkages are likely to inspire rapid growth of production, income, and employment of the economy [31]. Understanding the nature of intersectoral linkages in output may turn out to be instrumental in framing suitable policies which could ultimately help in inducing balanced growth pattern [46]. The contributions of agriculture, industry and service sectors for the overall economy growth of Ethiopia are varying with time span. The unevenness pattern of the contribution of sectors to GDP encourages an interest of investigating their interrelationships [34].

Therefore, the selection of strategic sectors is based on the capability of the sectors to generate forward and backward linkages to the subsequent sectors and its subsectors [37]. Thus, studying intersectoral linkages is essential, especially for a developing country [19]. However, the direction of causality linkage between agricultural, industrial and services sectors differs across countries [34], This needs to identify the causal linkage among sectors therefore after identifying the direction of causality between sectors, policy focuses need to be given to the sector which has higher linkage. Alternative method to identify the direction of transfer of resources amongst sectors is causality analysis, and the causal linkages will help explain the direction of resource transfers between sectors [35]. Accordingly, this paper studied the intersectoral linkages in Ethiopian economy using causality analysis and a time series data ranging from 1975 to 2017.

\subsection{Objectives of the Study}

The main objective of this study is to analyze the intersectoral linkages in Ethiopian economy and specifically to; i. Identify the existence of long-run growth relationships among agricultural, industrial and service sectors of the economy

ii. Test the direction of long-run and short-run causality among sectors

iii. Assess the dynamics effects of shocks in each respective sectors

\section{Review of Literature}

\subsection{Theoretical Literature Reviews}

\subsubsection{Definition and Concepts}

The linkage among the sectors can be described by backward and forward linkages and consumption and production linkages. Backward linkage refers to growth of a set of industries encourages the growth of those which supply raw materials. Whereas, when the growth of certain industries owing to the initial growth of those which supply raw materials is known as forward linkages [46]. The expansion of demand for agricultural inputs such as fertilizer, improved seeds and machineries can encourage industrial and service sector activities through backward linkages. Other sector activities could be stimulated by agriculture at the same time via forward linkages such as the requirement to process agricultural products [42]. The production linkages typically arise from the interdependence of the sectors for satisfying the needs of their productive inputs whereas consumption linkages / demand linkage which arises from the interdependence of the sectors for meeting final consumption [31]. The interaction between agriculture growth and sectoral growth extensively studies in developing countries on the theoretical and empirical. [25]

\subsubsection{Theories on Economic Development}

\section{The Lewis model of development}

In Lewis model of development, the economy has only two sectors; an agricultural, traditional, rural and subsistence sector and, an industrial, urban and capitalist sector. In the subsistence sector, the marginal productivity of labour is very low or closer to zero. Suggesting that there is underemployment under the agricultural sector, which is a potential supply of labour to the modern sector. These underemployment labours could be reduced (through migration) without decreasing output in traditional sector and capitalists in the modern sector can have a good supply of labour at the same wage rate [12]. Since the model assumes that the $\mathrm{MP}_{\mathrm{L}}$ is negligible or zero, the wage in the traditional sector remains constant at a subsistent level.

In modern sector, the supply of labour exceeds demand and the wage rate remains constant at subsistence level; hence, the rate of profits is maximized and this profit is going to be reinvested to create new capital at a maximum rate. Hence, the reinvestment and the expansion capital lead to new employment. The same process of profit-investmentemployment continues until all the surplus of labour vanishes. Beyond this, hiring of workers at the initial wage rate become impossible and any further withdrawal of 
additional workers from the traditional sector leads to an improvement of the marginal productivity of labour in this sector. However, before the surplus of labour in traditional sector is eliminated, the wage rate in subsistence sector may increase and affect the further expansion of the capitalist sector. Hence the marginal productivities of workers in both sectors come to be equal [12].

Unbalanced and Balanced growth theory

The theory of unbalanced growth which was promoted by Hirschman advocates on the need of investment in selected and strategic sectors of the economy at a time Therefore other sectors would spontaneously develop themselves via backward and forward linkage effects. Thus the strategic sectors in the economy should get priority over others as far as the resources are concerned. The expansion of strategic sectors in addition to providing the benefits to the owners it also encourages the growth of other set of industries through backward and forward linkages. This needs the understanding of sector linkages of the economy [27]. The balanced growth theory on the other hand advocates that the government of any developing country needs to make large investments in different economic sectors simultaneously [36]. Nurkse, the founder of the theory recognized that the expansion and intersectoral balance between agriculture, industry and service is necessary so that each of these sectors creates a market for the products of the other and in turn, it supplies the required raw materials for growth and the success of the other [36].

\subsubsection{The role of Agriculture and Industry in the Process of Economic Development}

Agricultural and industrial sector have their respective role to play in the process of economic development. However their significance differs depending on the level of the structure of economies at a certain time.

Agriculture and Economic Development: One major feature of Economic development is that the considerable increase in demand for agricultural products. The expansion of exports of agricultural products is one way of increasing income and foreign exchange earnings for developing countries, mostly in the early stages of economic development. The sector provides labor force for modern sectors of the economy; it can be a source of capital required for investment on non-agricultural sectors and a destination for industrial products [17]. However, in most developing countries, although large amounts of resources such as land and labor are engaged in agriculture, they are being exploited at lower stages of productivity [22].

Industrialization and Economic Development: When an economy gets expanded, the share of the agricultural output to GDP declines, and the share of industrial sector grow. In this case industrialization has a number of roles to play in the process of development. Industrialization is necessary to provide employment opportunities to the unemployed workers in the agricultural sector especially in developing countries. It provides supplies farm inputs so as to increase productivity in the agricultural sector. It is also argued, industrialization brings increasing returns and economies of scale while agriculture does not [17]. Fourthly, it prevents worsening in the terms of trade of primary products. In addition to this it brings urbanization, which in turn brings social transformation [17].

\subsection{Empirical Literature Reviews}

The dynamics of intersectoral linkages can be studied in three ways; through use of input-output tables, statistical analysis and econometric modeling exercises among various sectors of the economy. Studies reviewed for this study have used different methodology and found different conclusions. Some of them mentioned that the causality runs from agriculture to the rest of sectors whereas others mentioned in the reverse direction. This could be accrued due to the level of the proper roles of sectors in respective study countries.

\subsubsection{Ethiopian Perspective}

Few studies regarding sectoral linkages have been studied in Ethiopia. Using the social accounting matrix and cointegration analysis, [44] studied the relationship between agriculture and industry sectors in Ethiopia. The study revealed that agricultural sector has higher backward and forward linkage with the rest of the sectors. In Johanson cointegration analysis agricultural sector was found as weakly endogenous suggesting that the causality runs from industry to agriculture.

Using the social accounting matrix (SAM) - based multiplier, [37] studied the inter-sectoral linkages of Ethiopian economy. His result revealed that the agricultural sector in general have a strong combination with the rest the economy. The study also found that an exogenous increase in the demand for products of agricultural activities has a larger effect on the demand for both labor and capital. Alemu et al. [1] performed Granger causality tests between agricultural sector and the rest of the economy of Ethiopia. Accordingly a bi-directional causal relationship was found between agriculture and manufacturing sectors and, between agricultural and service sectors.

Kassahun [17] studied the long-run intersectoral linkages in Ethiopian economy. Using a co-integration method, the study found a long-run association ship between agricultural, industrial and service sectors growth. The study also confirmed, the complimentarily relationship between output in industry and agriculture but a negative relationship between growth in services and agricultural GDP. Furthermore, industrial and service outputs are found to be weakly exogenous to the system signifying the long-run causality runs from industrial and service outputs to that of agricultural. Xinshen et al. [46] estimated Agricultural Growth Linkages in Ethiopia. By using fixed and flexible price models, the study depicts that the growth in agricultural sector can bring about higher overall growth in economy and faster poverty reduction process compared to non-agricultural growth. The study further showed that economic growth strategies rely on recognizing a set of sectoral linkages by with agricultural growth contributes to the growth of rest of 
sectors in the Ethiopian economy.

\subsubsection{World Perspective}

Saikia [31] estimated the intersectoral linkage between the manufacturing and the rest of sectors of the Nigerian economy. The study employed VECM and Granger causality method and used quarterly time series data reaching from 1986 to 2010 . The results found a weak relationship between the manufacturing sector and the rest of sectors of the economy. The study further confirmed the absence of any causal relationship between the output of manufacturing sector and, real economic activities and financial sector output. Chebbi [5] assessed the growth linkage between agricultural sector and the other sectors of the Tunisian economy. Using a time series data and applying Johanson Co-integration and Granger causality, the study confirmed the presence of a long-run growth relationship between agricultural and other sectors of the economy.

João and Marta [14] investigated the existence of long-run relationships and causality among industry, agriculture and services in terms of value added and productivity in Portugal. Using trivariate VAR model of co-integration and causality techniques for the period 1970-2006, the found the growth of labour productivity in services and industrial sectors backs into the productivity growth of agricultural sector. However, the link was found to be weaker in the industry case. Kohansal [21] also examined the role of agricultural sector to economic growth of Iran. Using the bound test and time series data, the study found a long run equilibrium association between the variables; agricultural, services, mines and industrial and oil sectors found to have a positive and meaningful relationship towards economic growth.

Matahir [23] investigated the agricultural-industrial sectors relationship in Malaysia for period 1970 - 2009. The study adopted the Johansen co-integration, Granger and TodaYamamoto causality tests procedures. Accordingly, the result revealed that agricultural and industrial sectors are cointegrated in the long run and also showed that there is unidirectional causality from running from industrial to agricultural sector both in the short and long run period.

Naval [25] examined causal relationship between GDP and sectoral output growth in Indian economy. Using time series data and implementing Johansen's Co-integration test, IRF and VD, the study found bidirectional causality among sectors and GDP and, agricultural and industrial sector, while a unidirectional causality between agriculture and industry sector is found. The results of IRF and VD show that, the influence GDP forecast error by the services sector is the highest, followed by agriculture and industry sectors, while the influence to the agriculture sector forecast error by GDP is the highest, implying agriculture as the leading economic activity in the country. Uddin [40] also studied the contribution of agriculture, industry and services sectors to economic growth of Bangladesh. By using time series data, co-integration analysis and granger causality, the study indicated that the sectoral growth has positive and significant relationship with economic growth. A bi-directional causality between agricultural and GDP and, industrial and agricultural sectors and a uni-directional causality from services to agricultural and from industrial to services sectors were found.

Sikhosana [34] examined the interrelationships between agriculture and other sectors of the Swaziland economy and their impact on economic growth. Using a time series data and, bound test approach to co-integration and Granger causality, the study confirmed the presence of a long run association ship among agriculture, the rest of sectors of the economy and overall economic growth. In addition, bidirectional causality between agriculture and economic growth, unidirectional causality between agriculture and services, running from services to agriculture were found. Katircioglu [18] investigated the possible co-integration and causal relationship between economic growth and sectoral output growth in North Cyprus. The study result revealed that agricultural sector has a long-run relationship with economic growth and gives direction to industry as it provides raw materials to that sector. Additionally, uni-directional causality existed running from real GDP to industrial output and to services sector.

\section{Methodology of the Study}

\section{Introduction}

The dynamics of intersectoral linkages in an economy can be studied in three ways; through use of input-output tables, statistical analysis and based on econometric modeling exercises among various sectors of the economy [11]. This paper used the third approach of time series econometric model.

\subsection{Data type and Data Sources}

The study used a secondary a time series data of sectoral value added and GDP ranging from 1975 up to 2017. The data are obtained from Ministry of Finance and Economic Cooperation (MoFEC) of Ethiopia. The study has used three variables namely, agricultural, industrial and service sectors. The definition, division and classification of sectors are based on Ministry of Finance and Economic Cooperation (MoFEC) of Ethiopia classification and the data are based on 2011 constant price. Accordingly the agricultural sector includes; Agriculture, Hunting, fishing and Forestry. The industry sector has five major sub-sectors; large and medium scale manufacturing, small scale industry and handcrafts, electricity, water, mining and construction subsectors. The service sector comprises trade, hotels and restaurants, transport and communications, banking and insurance, real estate, public administration and defense, education, health and domestic and other services.

\subsection{Model Specification}

Given three endogenous variables such as; agricultural, industrial and service sectors, the basic model can be mathematically expressed with the following estimation 
equation.

$$
\mathrm{G}_{\mathrm{i}}=f(\text { LNIND, LNAGR, LNSERV) }
$$

Where the $G_{i}$ is the growth of sector i, and LNIND, LNAGR and LNSERV are stands for a natural $\log$ of industrial, agricultural and service sector value added, respectively (based on 2011 constant price of Birr). The above equation expresses the growth of a sector is as a function of the other two sectors and its own previous year performance.

Vector Autoregressive and Vector Error Correction Model (VECM)

Economic variables have short run behavior that can be captured through dynamic modeling. If there is long run relationship among the variables, an error correction model can be formulated that portray both the dynamic and long run interaction between the variables. If the time series are not stationary, the co-integration approach and vector error correction model (VECM) are used to examine the relationship among non-stationary variables [35]. In a VAR model all variables are treated as endogenous and stated as linear functions of their own and lags of the other variables under consideration, and also additional exogenous and deterministic variables, such as an intercept and a time trend. Let $\mathrm{Zt}$ denote the column vector that contains the three sector series at time $t$ with k-lags. We can specify the VAR (k) model as:

$$
\mathrm{Zt}=\mathrm{A} 1 \mathrm{zt}-1+\ldots . \text { Akzt-k }+\mu+\phi \mathrm{Dt}+\xi \mathrm{t}
$$

where $\mathrm{Zt}$ is a $(\mathrm{nx} 1)$ vector of stochastic I (1) variables, $\mathrm{Ai}$ $(\mathrm{i}=1, \ldots, \mathrm{k})$ is $\mathrm{n} \times \mathrm{n}$ matrix of parameters, $\mu$ is a vector of deterministic component (i.e., a constant and trend), $\mathrm{D}$ is a vector of dummies (such drought, war or regime change) and $\xi \mathrm{t} \sim \mathrm{IN}(\mathrm{O}, \Sigma)$ is a vector of error term and $\mathrm{t}=1, \ldots, \mathrm{T}(\mathrm{T}$ is the number of observation). The above model can be reparameterized to give a vector error correction model (VECM). That is, adding and subtracting $(A k-1, \ldots . ., A 2-A 1$ I) $Z t-k$ from equation 2 (I being the identity matrix) results the following specification.

$$
\Delta \mathrm{Z}_{\mathrm{t}}=\Gamma_{1} \mathrm{Z} \Delta_{\mathrm{t}-1}+\ldots .+\Gamma \mathrm{k}-1 \Delta \mathrm{Z}_{\mathrm{t}-\mathrm{k}+1}+\pi \mathrm{Z}_{\mathrm{t}-\mathrm{k}}+\mu+\phi \mathrm{D}_{\mathrm{t}}+\xi_{\mathrm{t}}
$$

Simplifying equation (3) gives

$$
\begin{gathered}
\Delta Z t=\sum_{i=1}^{k-1} \Gamma \mathrm{i} \Delta \mathrm{Zt}-\mathrm{i}+\pi \mathrm{zt}-\mathrm{k}+\mu+\phi \mathrm{Dt}+\xi \mathrm{t} \\
\text { where } i=1, \ldots, k-1, \Gamma i=-\left[I-\sum_{j=1}^{i} A j\right] \Gamma \mathrm{i} \text { is allowed to vary without restriction } \\
\pi=-\left[I-\sum_{j=1}^{k} A j\right]
\end{gathered}
$$

If there is any long run relationship (i.e., cointegration among the variables) we can rewrite equation (4) to come up with the following VECM specifications.

$$
\begin{array}{r}
\triangle A G R t=\alpha 1+\sum_{i=1}^{k} \beta i \Delta A G R t-i+\sum_{i-0}^{k} \theta \Delta X j t-i+D R T t+R E G t+\gamma E T C t-1 \\
\Delta I N D t=\alpha 2+\sum_{i=1}^{k} \beta i \Delta I N D t-i+\sum_{i-0}^{k} \theta \Delta X j t-i+D R T t+R E G t+\gamma E T C t-1 \\
\Delta S E R V t=\alpha 3+\sum_{i=1}^{k} \beta i \Delta S E R V t-i+\sum_{i-0}^{k} \theta \Delta X j t-i+D R T t+R E G t+\gamma E T C t-1
\end{array}
$$

Where, $\triangle$ AGRt, $\triangle \mathrm{INDt}$ and $\triangle \mathrm{SERVt}$ are the lagged first difference of agriculture, industry and service sectors, respectively. DRTt and REGt represent the dummies for drought and regime change, respectively. $\Delta \mathrm{Xjt}-\mathrm{i}$ is a vector of the first differences of the explanatory variables, $\alpha$ is constant term and $\mathrm{ECT}_{\mathrm{t}-1}$ represents the error correcting term (speed of adjustment to the long run equilibrium). $\mathrm{K}$ is the maximum lag of variables under consideration..

If there is only one cointegrating vector and if the endogenous and exogenous variables are identified in the long run analysis, we can develop the VECM by conditioning on the exogenous variables. In this case, only the error correcting terms of the endogenous variables appear in the error correction model. The coefficient of the lagged errorcorrection term $\left(\mathrm{ECT}_{\mathrm{t}-1}\right)$, is a short-term adjustment coefficient and represents the proportion by which the longterm disequilibrium in the dependent variable is being corrected in subsequent period [7].

\subsection{Econometric Procedure}

Most of the discussions for the objectives of the study have done through econometric analysis. This subsection comprises unit root tests, Johanson cointegration, vector error correction model and dynamic impact analysis.

\subsubsection{Unit Root Test}

This study used the augmented Dickey Fuller (ADF) and Phillips-Perron (PP) tests assess the stationarity and unit-root characteristics of variables. The study used the Dickey-Fuller (DF) test might seem reasonable to test the existence of a unit 
root in the series using the most general form of model. Test The Phillips-Perron [28] test is well suited for analyzing time series whose difference may follow mixed autoregressive moving average $(\mathrm{p}, \mathrm{q})$ processes of serial correlation and hetroskedasticity in testing the regression.

\subsubsection{Johanson Co-integration Approach}

After the evaluation of the Univariate properties of the time series, the next step is to determine the level of cointegration between variables. Two or more integrated one variable are said to be co-integrated if there exist a linear combination of them that is stationary [6]. This study used Johanson co-integration technique. Unlike the Engle-Granger methodology, the Johanson methodology allows to test the presence of more than one cointegration vector. In addition to this, it allows to estimate the model without restricting the variables as endogenous and exogenous a prior. In identifying the number of co-integrating vectors in the system, the Johansen procedure provides $\mathrm{n}$ eigenvalues represented by $\lambda$ whose magnitude measures the extent of correlation of the co-integration relations with the stationery elements in the model. In Johanson approach to identify the number of co-integrating vectors in the system, the Lambda $\max (\lambda \max )$ and Lambda trace ( $\lambda$ trace) statistics are used. They are obtained from the following formulas.

$$
\begin{array}{r}
\lambda_{\max }=-\mathrm{T} \log \left(1-\lambda_{\mathrm{r}+1}\right), \mathrm{r}=0,1,2,3 \ldots ., \mathrm{n}-1 \\
\lambda \text { trace }=-T \sum_{i=r+1}^{n} \log (1-\lambda \mathrm{i})
\end{array}
$$

Where $T$ is the sample size and $\lambda \mathrm{i}$ is estimated eigenvalues. The trace statistics tests the null hypothesis of less than or equal to ' $r$ ' cointegrating vectors against the alternative of ' $r$ '. Whereas the $\max \left(\lambda_{\max }\right)$ statistic tests the null hypothesis that there are ' $r$ ' cointegrating vectors against the alternative of ' $r+1$ '. The distributions of both test statistics follow Chi-square distributions.

\subsubsection{Granger Causality Test}

The idea of granger causality relates to whether one variable can help improve the forecast of another. A variables
$\mathrm{Y}$ is said to be caused by a variable $\mathrm{X}$ if $\mathrm{Y}$ can be predicted better using past values of both $\mathrm{Y}$ and $\mathrm{X}$ than from past values of $Y$ only. This study used Granger causality test.

\subsubsection{Variance Decomposition and Impulse Response}

In Vector Error Correction Model, F- and t- tests can be interpreted as within-sample causality tests. They can specify only the Granger-causality of the dependent variable within the sample period. On the other hand Variance decompositions (VDCs), by separating the variance of the forecast error of any variable into the proportions attributable to shocks in each variable in the system including its own, can provide an indication for dynamic effects [7]. In order to estimate the total effects of one sector on the other, the model should include all the inter-sectoral linkages. One-way to estimate the total effect is by using an impulse response function (IRF) and it suggests the effect of a one standard deviation shock in one of the endogenous variables [35].

\subsubsection{CUSUM Test}

The most commonly used test for the structural stability is cumulative sum of square (CUSUM). If the estimated residuals crossed either of upper or lower bound limits, which are determined by using 95 percent confidence intervals, the null hypothesis of no structural break is rejected. And if the result shows evidence for the presence of structural break, the model should include a set of dummy variables to reflect the structural break. In addition to this the common diagnostic tests such as Normality test, Heteroskedasticity and vector autocorrelation tests are used.

\section{Result and Discussion}

\subsection{Sectoral Composition of Ethiopian Economy}

In recent times the Ethiopian economy is becoming one of the fastest growing economies in the world; however the report of the rate of growth is varied depending on the data producing institutions.

Table 1. The performance of the economy across the two regime periods.

\begin{tabular}{llll}
\hline \multirow{2}{*}{ Sectors } & Description & Period & \\
\cline { 3 - 4 } & & Command Economy (1975-1990) & Free market Economy (1991-2017) $^{\text {(19) }}$ \\
\hline \multirow{3}{*}{ AGR } & Value added & 76227.7 & 152937.3 \\
& Growth rate & 1.385 & 4.67 \\
& \% share to GDP & 62.26 & 51.26 \\
\multirow{2}{*}{ INDS } & Value added & 11219.03 & 39432.72 \\
& Growth rate & 2.54 & 9.33 \\
& \% share to GDP & 9.1 & 10.6 \\
SER & Value added & 35302.51 & 137053.9 \\
& Growth rate & 2.85 & 7.11 \\
\multirow{2}{*}{ GDP } & \% share to GDP & 28.6 & 38.2 \\
& Value Added & 122749.2 & 329423.9 \\
\hline
\end{tabular}

Source: authors' computation based on MoFEC Data. 
As table 1 shows, the average value added of agricultural, industrial and service sectors from the year 1975-1990 was 76227.7, 11219.03 and 35302.51 (in million birr) respectively. In earlier time agricultural sector was producing more than half of GDP. From the year 1991-2017 the average value added of agricultural, industrial and service sectors is 152937.3, 39432.72 and 137053.9 million birr respectively. Service sector is becoming the fastest growing sector in Ethiopian economy. It has been growing at the rate of $2.85 \%$ from $1975-1990$ and $7.11 \%$ from $1991-2017$ on the average. Currently the sector covers more than $40 \%$ gross value added share of the economy.

The percentage share has been adjusted through time in which the agricultural sector share has been falling, while the share service sector increases and industrial sector nearly stagnating. The average percentage share of sectors to GDP from the year 1975-1990 was 62.26, 9.1 and 28.6 for agricultural, industrial and service sectors respectively. After the command economy system replaced by the market economy system the average percentage share of agricultural, industrial and service sectors to GDP changed to 51.26, 10.6 and 38.2, respectively. The economy performed higher growth rate under free market economy with the annual average growth rate of 6.5 percent. However the percentage share of GDP of industrial sector in both systems is very low and, somewhat the share of services sector is becoming larger particularly in recent times. This is not good for emerging economies like Ethiopia.

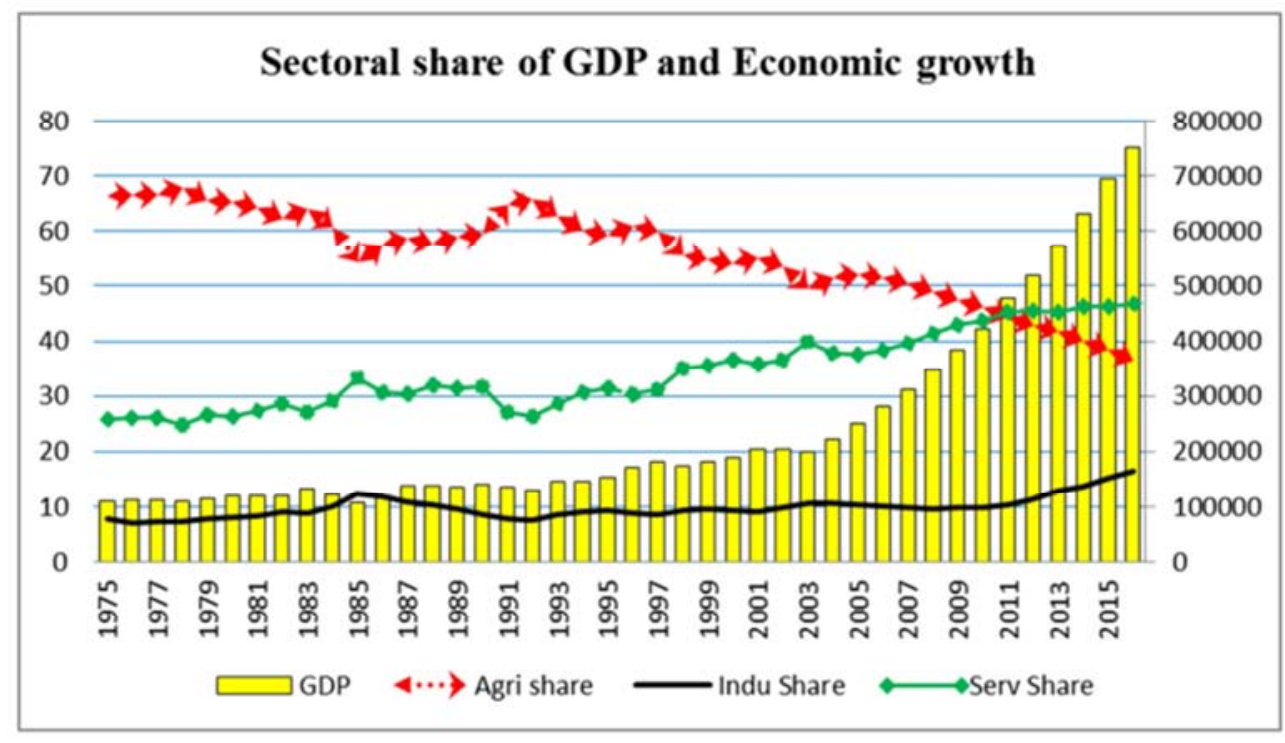

Source: author's computation based on MoFEC Data.

Figure 1. Sectoral value added shares and economic growth.

'Figure 1' depicts the sectoral share of GDP and economic growth over the study period (the left hand vertical axis represents the sectoral share to GDP in percentage and the right side vertical axis shows the GDP in million Birr). The share of agriculture sector was dominant up to the year 2011 . It was covering more than $45 \%$ of the national output. Starting 2011 year the service sector came to the lead, while the industry sector is fluctuating between 7 and 14 percent. The share of agricultural sector has been declining almost throughout the study year while the share of service sector has increasing. This is due to the fact that different service components like: banking and insurance, education and training centres, health institutions, different transport services, trade, tellecomunication infrastractures, hotel and toursim servises are expanding following the eonomc growth and globalization. The share Agriculture sector especially starting from the year 1992 onwards has been declining. However, since the sector is leading in terms of employment source of inputs and foreign exchange earnings, the declining share of agriculture in GDP does not mean the role of the sector is shrinking.

'Figure 2' depicts the growth rate of GDP, agriculture, industry and service sectors starting from 1976 up to 2017. The industry and service sectors have got little negative growth rate compared to agriculture sector. The growth rate of agricultural sector is fluctuating over the study years - this is because of the sector is backward and rain dependent. This paves way to frequent drought and famine. Especially the growth rate of agricultural sector in the year of 1985 was negative. At this time one of the severe droughts in Ethiopian history that took hundreds of thousands of lives people's and retarded the economy-was occurred. The growth rate of GDP is contributed by the three sectors. As 'figure 3' show agriculture sector has been most growth rate provider for GDP up to 1999. Starting from 1999 service sector has provided most growth rate of GDP. 


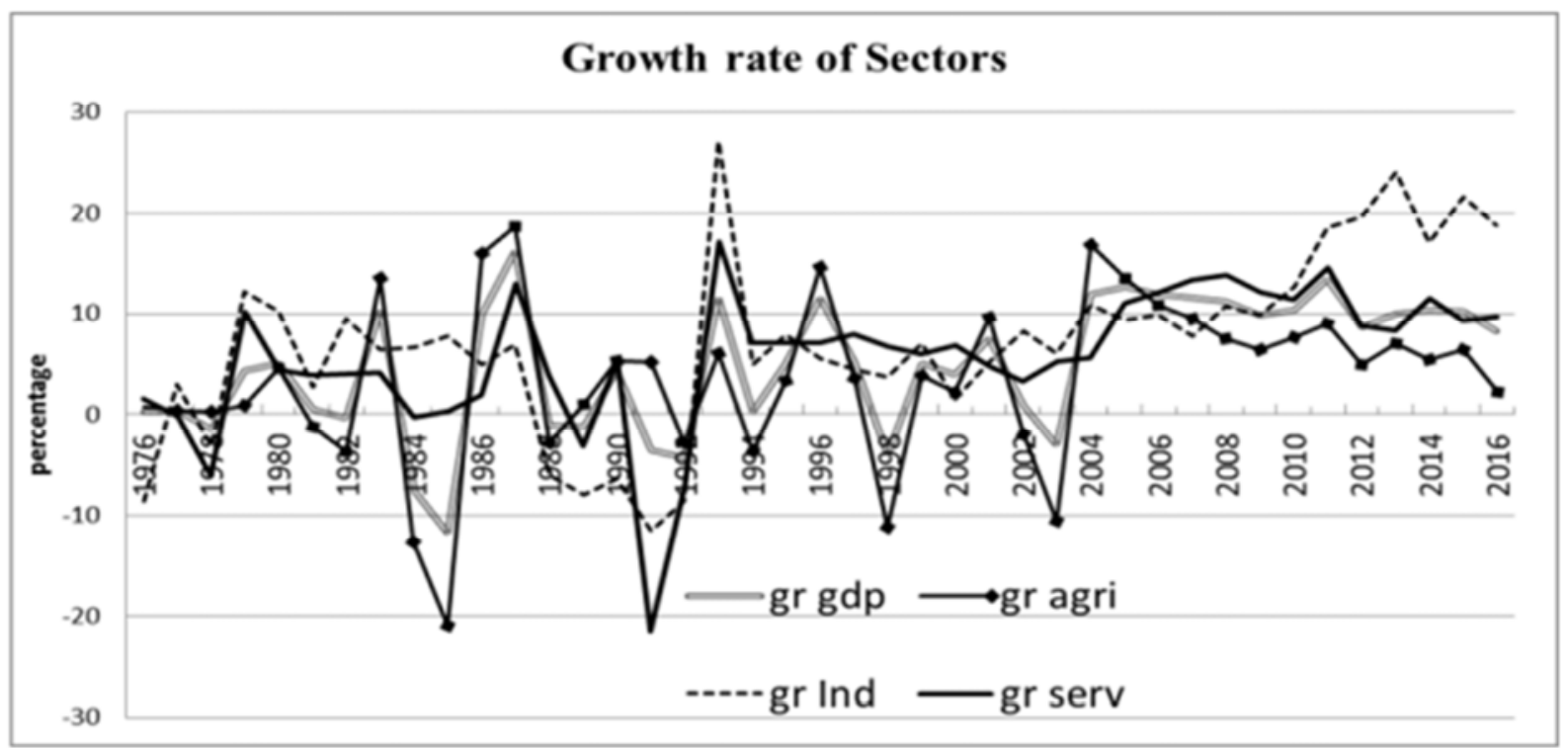

Source: author's computation based on MoFEC Data.

Figure 2. Growth rates of sectors.

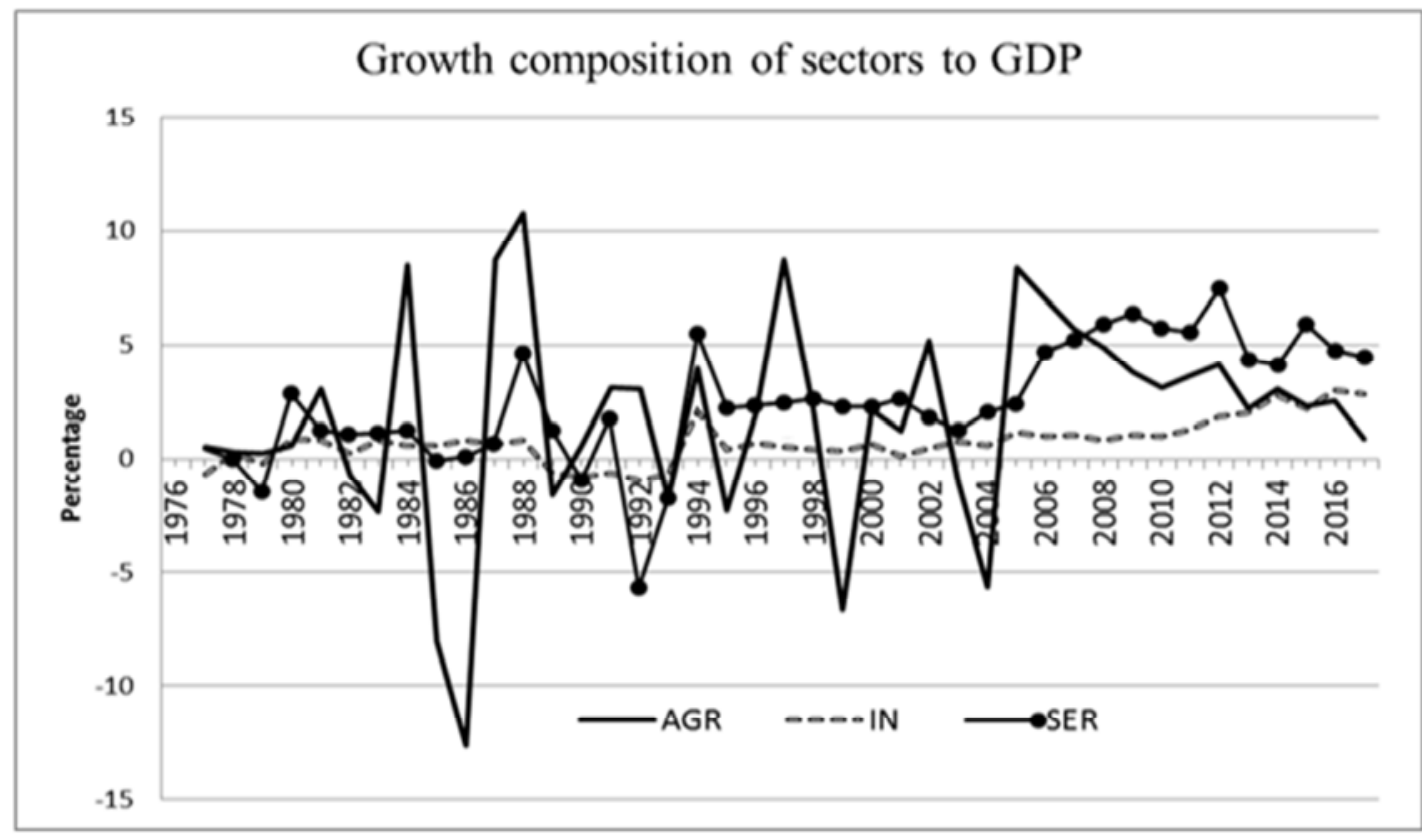

Source: author's computation based on MoFEC Data.

Figure 3. Growth composition of sectors to GDP.

This is due to the fact that role sectors to GDP has shifted from agriculture sector to service sector, however whether this is due to the underpinning of structural transformation of the economy or not is undecided. In 1985 the growth rate GDP contributed by agriculture sector was high (although it is negative). From 1990 to 1993 the growth rate of GDP contributed by industry and service sector were negative this is because of the civil war had reached in its pick and secession of Eritrea which has stunted the economy, especially the industrial and the service sectors.

\subsection{Regression Analysis}

\subsubsection{Unit Root Tests}

In order to test stationary of the variables included in our models, the augmented Dickey Fuller and Phillips Peron test are employed, and all the tests were runs on both $1 \%$ and $5 \%$ level of significance. The unit root test results are reported under 'tables 2 and 3' below. 
Table 2. Augmented dickey fuller stationary test result.

\begin{tabular}{|c|c|c|c|c|c|c|c|c|}
\hline at Level & & & & & & & & \\
\hline \multirow{3}{*}{ Variables } & \multicolumn{4}{|l|}{ Intercept } & \multicolumn{4}{|c|}{ Intercept and trend } \\
\hline & \multirow{2}{*}{ Statistics test } & \multicolumn{2}{|c|}{ Critical values } & \multirow{2}{*}{ P-value } & \multirow{2}{*}{ Statistics test } & \multicolumn{2}{|c|}{ Critical values } & \multirow{2}{*}{ P-value } \\
\hline & & $1 \%$ & $5 \%$ & & & $1 \%$ & $1 \%$ & \\
\hline $\ln A G R$ & 2.196269 & -3.61045 & -2.93898 & 0.9999 & -0.729658 & -4.211868 & -3.529758 & 0.9635 \\
\hline $\operatorname{lnIND}$ & 4.603567 & -3.60099 & -2.935001 & 1.0000 & 1.422163 & -4.198503 & -3.523623 & 1.0000 \\
\hline $\begin{array}{l}\ln S E R \\
\text { at } 1^{\text {st }} \text { Difference }\end{array}$ & 3.349313 & -3.60098 & -2.935001 & 1.0000 & -0.336123 & -4.198503 & -3.523623 & 0.9868 \\
\hline $\mathrm{D}(\ln \mathrm{AGR})$ & $-6.2807^{*}$ & -3.61045 & -2.938987 & 0.0000 & $-7.477034 *$ & -4.211868 & -3.529758 & 0.0000 \\
\hline $\mathrm{D}(\ln I N D)$ & $-3.4983 * *$ & -3.60559 & -2.936942 & 0.0132 & $-4.222361 *$ & -4.205004 & -3.526609 & 0.0096 \\
\hline D (lnSER) & $-4.19310 *$ & -3.60559 & -2.936942 & 0.0020 & $-5.240585^{*}$ & -4.205004 & -3.526609 & 0.0006 \\
\hline
\end{tabular}

Source: EViews 10 result. * and $* *$ indicate $1 \%$ and $5 \%$ level of significance, respectively.

Table 3. Philip Perron stationary test result.

\begin{tabular}{|c|c|c|c|c|c|c|c|c|}
\hline \multicolumn{9}{|l|}{ Level } \\
\hline \multirow{3}{*}{ Variables } & \multicolumn{4}{|l|}{ Intercept } & \multicolumn{4}{|c|}{ Intercept and trend } \\
\hline & \multirow{2}{*}{ Statistics test } & \multicolumn{2}{|c|}{ Critical values } & \multirow{2}{*}{ P-value } & \multirow{2}{*}{ Statistics test } & \multicolumn{2}{|c|}{ Critical values } & \multirow{2}{*}{ P-valuc } \\
\hline & & $1 \%$ & $5 \%$ & & & $1 \%$ & $5 \%$ & \\
\hline $\ln A G$ & 2.050431 & -3.600987 & -2.935001 & 0.9998 & -1.125279 & -4.198503 & -3.523623 & 0.9122 \\
\hline $\ln I N$ & 3.519869 & -3.600987 & -2.935001 & 1.0000 & 0.719891 & -4.198503 & -3.523623 & 0.9995 \\
\hline $\operatorname{lnSER}$ & 3.349313 & -3.600987 & -2.935001 & 1.0000 & -0.427287 & -4.198503 & -3.523623 & 0.9831 \\
\hline \multicolumn{9}{|c|}{$1^{\text {st }}$ Difference } \\
\hline D (lnAGR) & $-5.777208 *$ & -3.605593 & -2.936942 & 0.0000 & $-10.56770 *$ & -4.205004 & -3.526609 & 0.0000 \\
\hline $\mathrm{D}(\ln I N D)$ & $-3.615361^{*}$ & -3.605593 & -2.936942 & 0.0098 & $-4.361615^{*}$ & -4.205004 & -3.526609 & 0.0067 \\
\hline $\mathrm{D}(\operatorname{lnSER})$ & $-4.202852 *$ & -3.605593 & -2.936942 & 0.0020 & $-5.240585^{*}$ & -4.205004 & -3.526609 & 0.0006 \\
\hline
\end{tabular}

Source: EViews 10 result. * and ** indicate $1 \%$ and $5 \%$ level of significance, respectively.

At level the absolute values of the calculated test statistics for the three variables are less than its critical value at $5 \%$ significance level both with intercept and intercept \& trend. So the null hypothesis that each variable has unit root cannot be rejected by the ADF test. However, after applying the first difference, we reject the null hypothesis since the data appears to be stationary at first difference. Accordingly all variables are integrated of order one I (1). Moreover the Phillips Perron test confirmed this result.

\subsubsection{Cointegration Analysis}

Before applying Co-Integration test, it is necessary to determine the appropriate lag length and check the stability of the VAR. The lag length is selected using Akaike Information Criterion (AIC) Schwarz Information Criterion (SIC) and Hannan-Quinn Information Criterion (HQIC). The more lags we include, the more initial values we lose. If we include too few lags, the size of the test will be incorrect [43].

Table 4. VAR Lag Order Selection Criteria.

\begin{tabular}{lllllll}
\hline \multicolumn{2}{l}{ Endogenous variables: LN_IND LN_AGR LN_SERV } & & & & \\
\hline Lag & LogL & LR & FPE & AIC & SC & HQ \\
\hline 0 & 26.66945 & NA & $5.96 \mathrm{e}-05$ & -1.213818 & -1.085851 & -1.167905 \\
1 & 165.9195 & 249.9360 & $7.51 \mathrm{e}-08$ & -7.893307 & -7.381442 & -7.709654 \\
2 & 177.7546 & 19.42179 & $6.55 \mathrm{e}-08$ & -8.038700 & -7.142936 & -7.717307 \\
3 & 202.1803 & $36.3254^{*}$ & $3.04 \mathrm{e}-08^{*}$ & $-8.82976^{*}$ & $-7.55010^{*}$ & $-8.37063^{*}$ \\
\hline
\end{tabular}

*indicates lag order selected by the criterion.

Source: EViews 10 result.

As 'table 4' shows all criterions suggested that there should be three lag in VAR analysis that means two lag should be used in VECM. VAR lag exclusion test is also applied so as to check the suitability of the lag included for estimation techniques.

Table 5. Unrestricted Cointegration Rank Test (Trace).

\begin{tabular}{llll}
\hline Hypothesized No. of CE (s) & Eigen value & Trace Statistic & Critical Value (0.05) \\
\hline None $*$ & 0.597807 & 43.966 & 35.19275 \\
At most 1 & 0.144740 & 9.3551 & 20.26184 \\
At most 2 & 0.085921 & 3.4138 & 9.164546 \\
\hline
\end{tabular}

Trace test indicates 1 cointegrating eqn (s) at the 0.05 level.

*denotes rejection of the hypothesis at the 0.05 level**MacKinnon-Haug-Michelis (1999) p-values.

Source: EViews 10 result. 
Since regime change (policy variation) and drought highly affect the number of co-integration among the sectors, the study treated these variables as an exogenous - by assigning dummies. Accordingly, ' 0 ' is assigned for command economy (prior to 1991) and ' 1 ' for Market economy (EPDRF era). Similarly ' 0 ' and ' 1 ' is assigned for the year that with and without extreme drought, respectively.

Table 6. Unrestricted Cointegration Rank Test (Maximum Eigenvalue).

\begin{tabular}{llll}
\hline Hypothesized No. of CE (s) & Eigen value & Max Eigen Statistic & Critical Value (0.05) \\
\hline None * & 0.59780 & 34.61125 & 22.2996 \\
At most 1 & 0.14474 & 5.941313 & 15.8921 \\
At most 2 & 0.08592 & 3.413865 & 9.16454 \\
\hline
\end{tabular}

Max-eigenvalue test indicates 1 co-integrating eqn (s) at the 0.05 level.

* denotes rejection of the hypothesis at the 0.05 level, **MacKinnon-Haug-Michelis (1999) p-values.

Source: EViews10 8result.

In Johansen co-integration procedure, the maximum Eigen value and the trace statistics evaluate the null hypothesis of there are exactly ' $r$ ' co-integrating vectors and there are at most ' $r$ ' co-integrating vector, respectively. The result of testing the number of co-integrating vectors is shown in 'table 5' and 'table 6' confirmed that there exists at least one meaningful long run relationship between the variables under consideration. Since we have one cointegration we take and normalize the first co-integration equation. And the result presented in 'table 7' below.

Table 7. Normalized Beta and Alpha coefficients.

\begin{tabular}{lll}
\hline \multicolumn{2}{l}{ Restricted cointegrating coefficients (beta coefficients normalized to industrial sector) (standard error in parentheses) } \\
\hline LN_IND & LN_AGR & LN_SERV \\
\hline 1.000000 & -0.903447 & -0.725116 \\
$(0.00000)$ & $(0.30783)$ & $(0.16081)$ \\
Adjustment (Alpha) coefficients (standard error in parentheses) & & \\
D (LN_IND) & $-0.280969(0.04721)$ & \\
D (LN_AGR) & $-0.110418(0.08560)$ & \\
D (LN_SERV) & $-0.093727(0.07378)$ & \\
\hline
\end{tabular}

Source: EViews 10 result.

The column of $\beta$ is the co-integrating parameter vector or, in other words $\beta$ spans of the co-integration space. The coefficients of $\alpha$ can be interpreted as adjustment coefficients measuring the relative importance of a deviation from equilibrium on a given endogenous variable.

\subsubsection{Long Run Equation}

In order to improve the statistical specification of the model test of exclusion from the cointegrating space and tests of weak exogeneity should be carried out. The zero restriction is imposed on each long run coefficient (beta) and the vectors for likelihood ratio tests are conducted. This test helps to identify unique cointegrating vector (it helps to determine which variable uniquely constitutes the cointegrating vector).

Restriction on beta $(\beta)$ coefficients: By imposing restrictions on the co-integration vector, to see whether one of the system variables can be excluded from the cointegration space or not becomes a common practice. 'Table 8 ' shows the test of zero restriction on long run parameters.

Table 8. Zero restriction for long run parameters ( $\beta$ ).

\begin{tabular}{llllll}
\hline Hypothesis & Industry & Agriculture & Service & Constant & LR test \\
\hline $\mathrm{H}_{1}$ & 0 & $*$ & 1 & $*$ & 17.12886 \\
$\mathrm{H}_{2}$ & 1 & 0 & $*$ & $*$ & 7.692949 \\
$\mathrm{H}_{3}$ & $*$ & 1 & 0 & $*$ & 0.000035 \\
\hline
\end{tabular}

Source: authors' computation. ' 0 ' indicates that the coefficient of a variable, $\mathrm{i}$, that has been restricted to zero and is equivalent to a test of long-run exclusion, a 1 indicates the variable used for normalization and a * indicates that a variable has been left unrestricted.

Accordingly all three variables are found to be integral to the system; therefore the specified co-integration space can be presented by 'table 9' as follows.

Table 9. Co-integration space.

\begin{tabular}{ll}
\hline Variables & $\boldsymbol{\beta}$ \\
\hline Industry & 1.000000 \\
Agriculture & -0.903447 \\
Service & -0.725116 \\
\hline
\end{tabular}

Source: EViews 10 result. 
Restriction on alpha $(\alpha)$ coefficients: The next step is to identify exogenous and endogenous variables in the system. If a certain variable is weakly exogenous to the system, it implies that its error correction term (the corresponding $\alpha$ - coefficient) excluded in the error correction model. In this case, weekly exogenous variables should be appeared in the right hand side of the VECM. This restricts the exogenous variables to be contemporaneous with the dependent variable.

Table 10. LR test restriction on Alpha coefficients.

\begin{tabular}{|c|c|c|c|}
\hline Model & Chi-square (1) & P-value & Decision \\
\hline Industry & 30.26220 & 0.000000 & Endogenous \\
\hline Agriculture & 2.009277 & 0.156340 & Weakly exogenous \\
\hline Service & 2.102419 & 0.147066 & Weakly exogenous \\
\hline
\end{tabular}

Source: authors' computation.

As it is appeared in 'table 10' only industrial sector is endogenous whereas agriculture and service GDP are weakly exogenous to the system. Therefore the long run relationship between the sectoral GDPs can be presented in equation (10), by putting the weakly exogenous variables on the right hand side of the equation.

LNIND $_{\mathrm{t}}=0.903447 \mathrm{LNAGR}_{\mathrm{t}}+0.725116 \mathrm{LNSERV}_{\mathrm{t}}-17.35952(10)$
Accordingly, a $1 \%$ increase in agricultural GDP leads to a $0.9 \%$ increase in industrial output. The results also suggest that in the long run a $1 \%$ in the service sector will result in $0.72 \%$ increase in industrial sector. The adjustment coefficients are presented as follows (Standard errors are in parenthesis) in 'table 11'.

Table 11. Adjustment coefficients (standard errors are in parenthesis).

\begin{tabular}{llll}
\hline Model & $\boldsymbol{\alpha}$ (standard errors are in parenthesis) & t-statistics & Comment \\
\hline$\Delta$ Ind & $-0.280969(0.04721)$ & -5.95142 & Significant \\
$\Delta$ Agr & $-0.110418(0.08560)$ & -1.28994 & Insignificant \\
$\Delta$ Serv & $-0.093727(0.07378)$ & -1.27034 & Insignificant \\
\hline
\end{tabular}

Source: EViews 10 result.

The non-significance of agricultural and service sector adjustment parameters or the weak exogeneity of thus two sectors further indicates that the long run causality is running from explanatory variables to the dependent variable, which is the industrial sector.

\subsubsection{Short Run Error Correction Models}

(i) Short run error correction model of industrial sector
'Table 12' below shows the short run dynamics model of the industrial sector. Where, D, Drt and Reg stand for difference, drought and regime respectively. From the table (12), in the short run industrial sector is positively and significantly affected by its past performance. This could be due to the fact that investors would be attracted by the progress of industrial sector and encouraged to invest on it.

Table 12. Error correction model for industrial sector.

\begin{tabular}{llll}
\hline \multirow{2}{*}{ Explanatory variables } & \multicolumn{2}{l}{ Dependent variable: D (LN_IND) } & T-statistics \\
\cline { 2 - 4 } & Coefficients & Std. error & 1.152055 \\
\hline D (LN_IND (-1)) & 0.185111 & 0.160679 & 5.887510 \\
D (LN_IND (-2)) & 0.824511 & 0.140044 & -2.607395 \\
D (LN_AGR (-1)) & -0.234341 & 0.089875 & -1.514377 \\
D (LN_AGR (-2)) & -0.151775 & 0.100222 & -0.926995 \\
D (LN_SERV (-1)) & -0.145626 & 0.157095 & -6.312278 \\
D (LN_SERV (-2)) & -0.981282 & 0.155456 & 4.105793 \\
C & 0.100312 & 0.024432 & $0.0000^{*}$ \\
DRT & 0.012518 & 0.016007 & -1.432080 \\
Regime & -0.029555 & 0.020638 & -5.951424 \\
ECt-1 & -0.280969 & 0.047210 & 0.3616 \\
R-squared & 0.81 & & $0.0000^{*}$ \\
Adj. R-squared & 0.76 & & $0.4405 *$ \\
F-statistic & 14.4 & & 0.1628 \\
Prob (F-statistic) & 0.000 & & $0.0000 *$ \\
Durbin-Watson stat & 2.08 & & \\
\hline
\end{tabular}

Breusch-Godfrey Serial Correlation LM Test: Prob=0.1717.

Heteroskedasticity Test: Breusch-Pagan-Godfrey Prob=0.0714.

Jarque -Bera Prob=0.00911.

Source: EViews 10 result. '*' and '**' indicates $1 \%$ and $5 \%$ level of significance respectively.

However, industrial sector is negatively affected by both agricultural and service sector in the short run. The expansion of service sector consumes trained workers and financial sources and, this reduces the availability of resources that 
could have been used by industrial sector. The growth of agriculture sector also possibly will result in increases consumption of productive resources, which is being used by industrial sector. The coefficient of the $E C_{t-1}$ has negative sign and it is significant for the industry sector approving further that the variables in the system have a long-run association ship. The estimated coefficient of $E C_{t-1}$ is -0.28 which implies that about $28 \%$ of the short-run deviations from industry sector will be adjusted each year to the longrun equilibrium level of industry sector. However, the coefficients of drought and regime are insignificant implying that in the short run they are inconsequential concerning the performance industrial sector.

(ii) Short run error correction model of agricultural sector According to 'table 13' short run result, agriculture is negatively associated with its own performance. Most of agricultural products of Ethiopia are contributed by small holder farmers. Most of these farmers cannot satisfy their wants at best and their basic needs at worst.

Table 13. Error correction model for agricultural sector.

\begin{tabular}{|c|c|c|c|c|}
\hline \multirow{2}{*}{ Explanatory variables } & \multicolumn{4}{|c|}{ Dependent variable: D (LN_AGR) } \\
\hline & Coefficients & Std. error & T-statistics & P-value \\
\hline D (LN_IND (-1)) & -0.684890 & 0.29133 & -2.35088 & $0.0257 * *$ \\
\hline D (LN_IND (-2)) & 0.333070 & 0.25392 & 1.31172 & 0.1999 \\
\hline D (LN_AGR (-1)) & -0.093351 & 0.16296 & -0.57286 & 0.5712 \\
\hline D (LN_AGR (-2)) & -0.679219 & 0.18172 & -3.73778 & $0.0008^{*}$ \\
\hline D (LN_SERV (-1)) & 0.623047 & 0.28483 & 2.18740 & $0.0369 * *$ \\
\hline D (LN_SERV (-2)) & -0.163947 & 0.28186 & -0.58165 & 0.5653 \\
\hline $\mathrm{C}$ & 0.069698 & 0.04430 & 1.57337 & 0.1265 \\
\hline DRT & -0.038231 & 0.02902 & -1.31723 & 0.1981 \\
\hline REGIME & 0.018260 & 0.03742 & 0.48798 & 0.6292 \\
\hline $\mathrm{EC}_{\mathrm{t}-1}$ & -0.110418 & 0.08560 & -1.28994 & 0.2073 \\
\hline R-squared & 0.420978 & & & \\
\hline Adj. R-squared & 0.241281 & & & \\
\hline F-statistic & 2.342716 & & & \\
\hline Prob (F-statistic) & 0.039878 & & & \\
\hline Durbin-Watson stat & 1.991525 & & & \\
\hline
\end{tabular}

Breusch-Godfrey Serial Correlation LM Test: Prob $=0.2743$.

Heteroskedasticity Test: Breusch-Pagan-Godfrey Prob $=0.3167$.

Jarque-Bera Prob $=0.667064$.

Source: EViews 10 result. '*' and '**' indicates $1 \%$ and $5 \%$ level of significance respectively.

As the time of agricultural product boost (thereby increases farmers' income), they automatically prefer to invest their income on other non-agricultural consumer products such as furniture, home commodities and even they might pay their past debt. Thus, they left with little income to invest on their farm. The other plausible explanation is when the income of smallholders reduces as a result of shrinkage in agricultural production (say because of drought); government agencies and NGOs might give special attention to farmers to make them self-reliant. This can be in the form of provision of; food, finance, seeds, fertilizers and etc. This will in turn increase agricultural production.

Table 14. Error correction model for service sector.

\begin{tabular}{|c|c|c|c|c|}
\hline \multirow{2}{*}{ Explanatory variables } & \multicolumn{4}{|c|}{ Dependent variable: D (LN_SERV) } \\
\hline & Coefficients & Std. error & T-statistics & P-value \\
\hline D (LN_IND (-1)) & 0.035357 & 0.251111 & 0.140803 & 0.8890 \\
\hline D (LN_IND (-2)) & 0.511104 & 0.218863 & 2.335270 & $0.0267 * *$ \\
\hline D (LN_AGR (-1)) & 0.055498 & 0.140459 & 0.395120 & 0.6956 \\
\hline D (LN_AGR (-2)) & -0.121245 & 0.156629 & -0.774089 & 0.4451 \\
\hline D (LN_SERV (-1)) & 0.098772 & 0.245510 & 0.402313 & 0.6904 \\
\hline D (LN_SERV (-2)) & -0.504328 & 0.242949 & -2.075860 & $0.0469 * *$ \\
\hline DRT & 0.016077 & 0.025016 & 0.642663 & 0.5255 \\
\hline REGIME & 0.015320 & 0.032253 & 0.474986 & 0.6384 \\
\hline ECt-1 & -0.093727 & 0.073781 & -1.270335 & 0.2141 \\
\hline R-squared & 0.396788 & & & \\
\hline Adj. R-squared & 0.209584 & & & \\
\hline F-statistic & 2.119552 & & & \\
\hline Prob (F-statistic) & 0.060799 & & & \\
\hline
\end{tabular}

Heteroskedasticity Test: Breusch-Pagan-Godfrey Prob=0.2075.

Breusch-Godfrey Serial Correlation LM Test: Prob=0.0750.

Jarque-Bera Prob $=0.00064$.

Source: EViews 10 result, $* *$ indicates the significance level at $5 \%$. 
Agricultural sector also negatively affected by one year earlier performance of industrial sector, and positively lagged service and industrial output. Drought, although statistically insignificant, affects agricultural sector negatively — as it was expected. The EPDRF regime influences agricultural sector positively but not statistically significant. The error correction term, however, is not significant.

(iii) Short run error correction model of service sector

As depicted by 'table 14' above, service sector is positively and significantly affected by lagged value of industrial sector. This means that industrial sector can provide different products such as; alcohol \& beverage, solar pulbs, cell phones etc. for sale. The expansion of telecommunication, road infrastructure and maintenance services could be as a result of boost in building \& construction, technology, metal \& iron production through backward and forward linkage. The growth of industrial production expands domestic markets which further arouse trading and commercial activities.

Agricultural sector affects the sector positively in first lag and negatively second lag although both are insignificant. Drought has a positive effect on service sector in the short-run. The vast population in Ethiopia lives in rural areas under which agricultural and related activities are dominant. In addition agricultural sector is a rain dependent which is always uncertain. This is because of the inconsistence of rainfall and climate condition of the country. At the time of rain failure, such large populations expose to drought and strive and begin migrating to urban areas. Therefore, due to the shrink in agricultural sector, some resources; such as labour force, shifts to service sector (such as urban informal sector). The occurrence of drought also diverts the government to focus on activities that are related to health care and nutrition. Regime also has a positive but insignificant effect on the service sector growth. Dergue regime gave less attention to private enterprises, private companies and other business organizations such as banks, insurances, exports and importers.

Model diagnostic tests

The three common criterions for model specification are: the residual of the model should be normally, Heteroskedasticity and serial correlation. First, the residuals are tested for normal distribution for each three models. The results of the test show that the residuals of both industrial and service sector models are not normally distributed. However, some researchers [2, 30] argue that the model can be accepted even though the residuals are not normally distributed. Second, the nullhypothesis of there is no Heteroskedasticity is tested and the results of the three models show that the value of test statistics $\left(\mathrm{Obs} * \mathrm{R}^{2}\right)$ is greater than 0.05 implying, the $\mathrm{H}_{0}$ : the residuals are homoscedastic is accepted. Third, the test conducted for serial correlation (Breusch-Godfrey Serial Correlation LM Test) is tested for all models and the probability value of Obs $* \mathrm{R}^{2}$ is greater than 0.05 for all models implying the residuals are not serially correlated. In addition to this, CUSUM test conducted. The null hypothesis of this test is that there is no structural break. Accordingly the Dummy variable is found enough to reflect the structural breaks over the study period. The results of CUSUM tests for industrial, agricultural and service sectors are reported in 'Figure 4', 'Figure 5' and 'Figure 6', respectively.

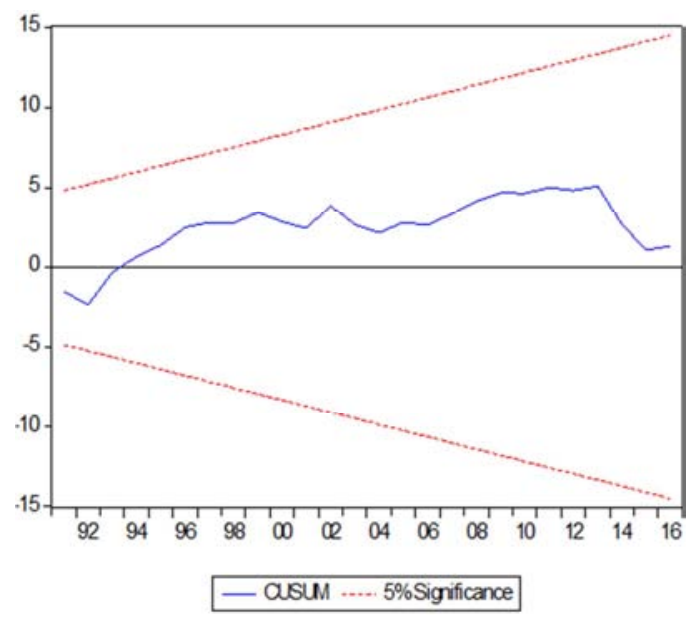

Figure 4. CUSUM test for industry sector.

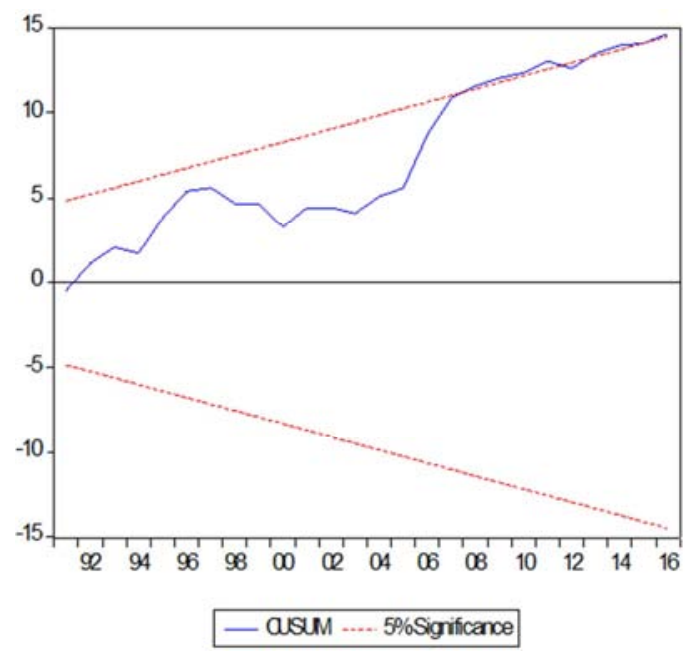

Figure 5. CUSUM test for Agriculture sector

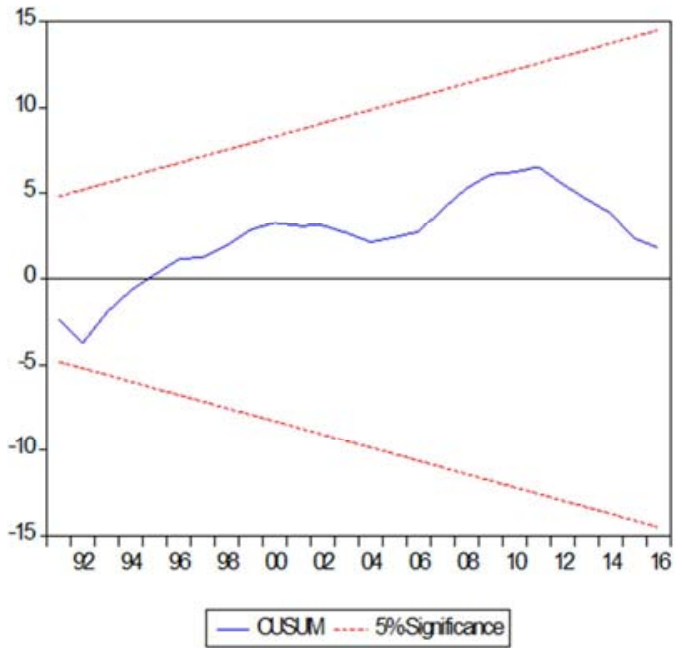

Source: EViews 10 result.

Figure 6. CUSUM test for service sector. 


\subsubsection{Causality Analysis}

\section{(i) Short run causality}

The short-run causality can be determined using a test on the joint significance of the lagged independent variables, using an F-test or Wald test. The null hypothesis is the lagged values of the independent variable are jointly Zero, meaning there is no short run causality running from the independent variables to the dependent one. The short run causality test result is presented in 'table 15'. From short-run causality analysis there is bi-directional causality between; industrial and service sectors, industrial and agricultural sectors and uni-directional causality between service sector and agricultural sector running from service to agricultural sector. But there is no causality between service sector and agricultural sectors running from agricultural to service sector.

Table 15. VEC Granger Causality/Block Exogeneity Wald Tests.

\begin{tabular}{|c|c|c|c|c|}
\hline \multicolumn{5}{|c|}{ VEC Granger Causality/Block Exogeneity Wald Tests } \\
\hline \multicolumn{5}{|c|}{ Sample: 19752017} \\
\hline \multicolumn{5}{|c|}{ Dependent variable: $D\left(L N \_I N D\right)$} \\
\hline Excluded & Chi-sq & df & Prob. & Conclusion \\
\hline D (LN_AGR) & 7.74494 & 2 & $0.0208 * *$ & Agriculture sector granger causes Industry sector \\
\hline D (LN_SERV) & 42.9324 & 2 & $0.0000 *$ & Service sector granger causes Industry sector \\
\hline \multicolumn{5}{|c|}{ Dependent variable: $D\left(L N \_A G R\right)$} \\
\hline Excluded & Chi-sq & df & Prob. & \\
\hline D (LN_SERV) & 4.87567 & 2 & $0.0873 * * *$ & service sector granger cause agriculture sector \\
\hline \multicolumn{5}{|c|}{ Dependent variable: $D\left(L N \_S E R V\right)$} \\
\hline Excluded & Chi-sq & df & Prob. & \\
\hline D (LN_IND) & 6.86498 & 2 & $0.0323 * *$ & Industry sector granger causes service sector \\
\hline $\mathrm{D}\left(\mathrm{LN} \_\mathrm{AGR}\right)$ & 0.93147 & 2 & 0.6277 & Agriculture does not granger cause service sector \\
\hline
\end{tabular}

Source: EViews 10 result. *, **and *** indicates a $1 \%, 5 \%$ and $10 \%$ level of significance respectively.

\section{(ii) Long run Causality}

From the vector error correction models, although all error correction terms are negative and less than one, only the industry sector equation is significant, implying the long-run causality is running from Agricultural and Service sector to the industry sector. Our long-run causality showed that, there is uni-directional causality between agricultural and industrial sectors running from agricultural sector to industrial sector, and between industrial and service sectors running from service sector to industrial sector. The absence of any long run causality between agricultural and service sectors reveals the weak long run association between them. The recent expansion of service sector at least is not preceded by the performance of agricultural sector. As part of service sector is determined by globalization and not merely depends on the performance of domestic economy, the neutrality of this sector with agriculture may not be a surprise result. The absence of long run causality between agricultural and service sectors also proves in the long run the performance of agricultural sector is not depending on service sector.

\subsubsection{Variance Decomposition}

The magnitude of variance explained is determined to be at the $10^{\text {th }}$ time horizon for all sectors and the result is presented in 'table 16 '.

Table 16. Magnitude of Variance explained at the 10th Time Horizon by Different Components.

\begin{tabular}{lll}
\hline At 10 $^{\text {th }}$ Time Horizon & S. E & Percent \\
\hline Variance in Industry explained by Agriculture & 0.263775 & 47.80998 \\
Variance in Industry explained by Service & 0.263775 & 24.75254 \\
Variance in Industry explained by itself & 0.263775 & 27.43748 \\
Variance in Agriculture explained by Industry & 0.217173 & 9.934834 \\
Variance in Agriculture explained by Service & 0.217173 & 13.26301 \\
\hline
\end{tabular}

\begin{tabular}{lll}
\hline At $\mathbf{1 0}^{\text {th }}$ Time Horizon & S. E & Percent \\
\hline Variance in Agriculture explained by itself & 0.217173 & 76.80216 \\
Variance in Service explained by Industry & 0.267183 & 41.09870 \\
Variance in Service explained by Agriculture & 0.267183 & 21.31639 \\
Variance in Service explained by itself & 0.267183 & 37.58491 \\
\hline
\end{tabular}

Source: author's computation.

Variance Decomposition of industrial sector: From the 'table 16' we can observe that agriculture sector alone explained 47.8 percent variance in industry sector at the $10^{\text {th }}$ time horizon, whereas the service sector explains 24.7 percent variance of industry sector. The remaining 27.43 percent of variance is explained by industry sector itself. Hence, the industry sector is strongly affected by agriculture sector in the long run, and, thus the long run causality seems to run from agriculture sector to industrial sector. Furthermore, starting from $5^{\text {th }}$ time horizon agriculture sector starts to explain much of variance in industrial sector. From the above justification, we can understand that in the long run agriculture sector can be the springboard to industrial sector.

Variance Decomposition of agricultural sector: Likewise, it is observed that 9.9 percent variance in agriculture is explained by industry sector, while service sector explains 13.26 percent variance in agriculture sector at the $10^{\text {th }}$ year time horizon. Here 76.8 percent of variance on agriculture comes out from itself. This shows that in the long run both service and industry sectors cause the agriculture sector less.

Variance decomposition of service sector: From the service sector it is observed that about 41 percent variance in service explained at the 10th time horizon is explained by Industry sector, whereas agriculture explains 21.3 percent variance in service sector at the same time horizon and the remaining 21.3 percent is explained by service sector itself. Hence, the industry sector affects service sector strongly in the long-run, 
and, the causality seems to run from industry sector to service sector. Industry sector can support service sector through providing different produced items.

\subsubsection{Impulse Response}

From impulse response results reported under 'figure 7' we can observe that agricultural sector highly affects the growth of industrial sector positively, after three periods of innovation. For service sector however, it has a negative effect up to 5 year and a positive effect after 5 year of innovation. The industrial sector as has a positive impact on service sector while, it has a small positive impact on agricultural sector after an innovation. The service sector has a negative impact on industrial sector up to five year, but has a big positive impact afterwards. The service sector also has appositive but a declining impact on agricultural sector. Therefore, the results of both IRs and VDs methods suggest that the agricultural sector can be playing the main role in influencing the overall growth of the economy via its linkages to other sector. This result can also be confirmed from our long run results.

\section{Reponseto OndesyoneSD (df. adusted)I movations}
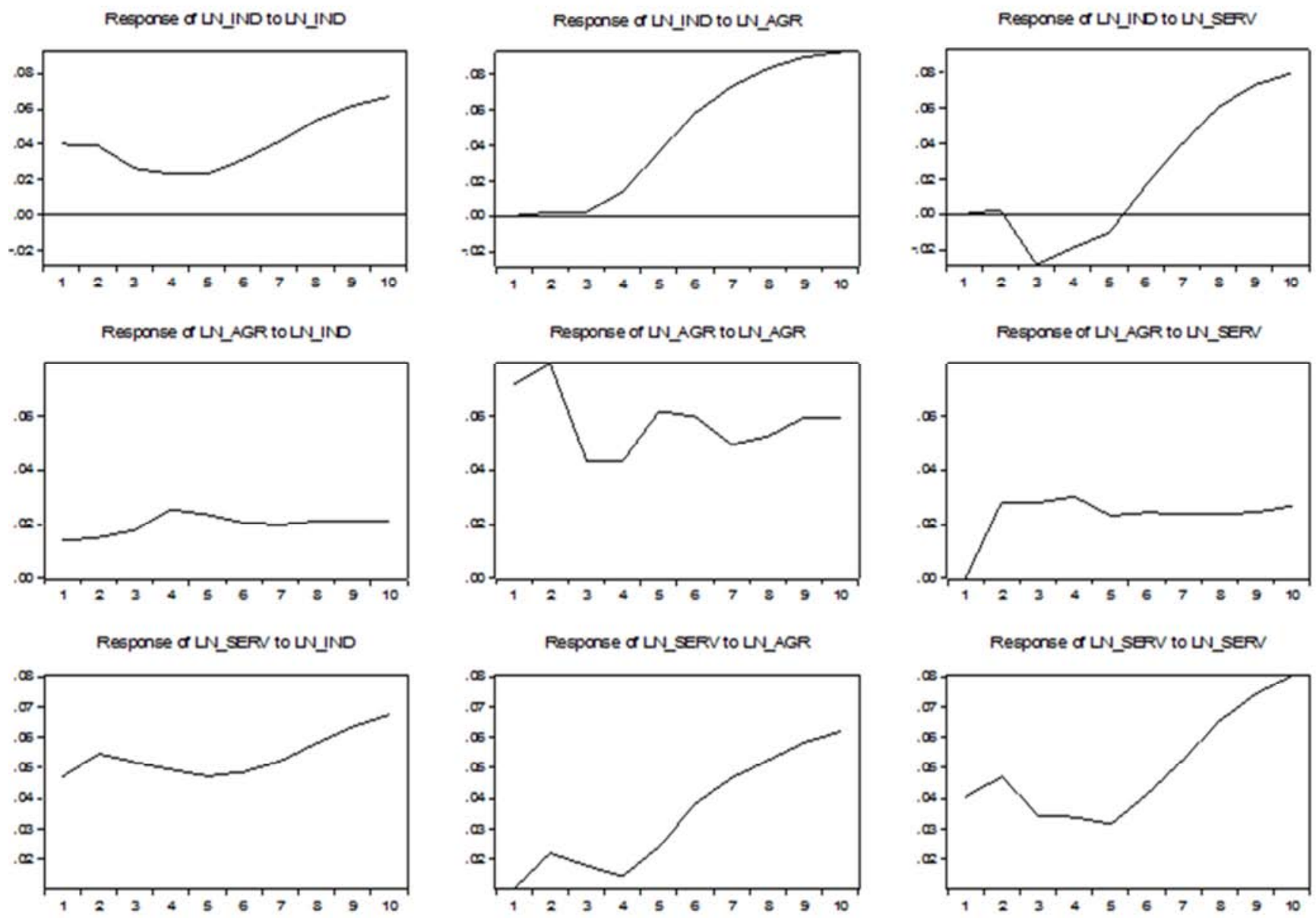

Figure 7. Impulse response functions.

Source: EViews 10 result.

Note: $\mathrm{Y}$ axis measures the impact and the $\mathrm{X}$ axis denotes the time trend.

\section{Conclusion and Recommendation}

\subsection{Conclusion}

The study analyzed intersectoral linkages in Ethiopian economy using a time series value added data on industrial, agricultural and service sectors ranging from 1975 to 2017. The study employed Johanson cointegration test, vector error correction (VECM) or restricted vector autoregressive (VAR) model granger causality test, variance decomposition functions and impulse response. The study found a stable long run relationship among three major sectors of the economy. Only the industrial sector is found to be endogenous to the system. The result is inconsistent with a similar study conducted by [17], whose study found that only agricultural sector is endogenous to the system.

The exogeneity of agricultural and service sectors indicate that, the causality is running from these two sectors to industrial sector. Here, it is agricultural and service sector that causes industrial sector. This result is not a surprise in a developing country whose economy is mainly dominated by agricultural sector, and where the service sector grows 
dramatically before conventional structural transformation transpired, through industrialization. The absence long run causality between agricultural and service sectors reveals the weak long run association between these sectors. In other words the recent expansion of service sector at least is not caused by the performance of agricultural sector. In the same fashion, in the long run the performance of agricultural sector is not depending on service sector. In the short run there is bi-directional causality between industrial and agricultural sector, and between industrial and service sector. The study also found that there exist uni-directional causality between service and agricultural sectors running from service to agricultural sector. However the result of long run causality is inconsistent with the short run one.

From dynamic causality analysis of variance decomposition, agricultural sector explained 47.8 percent variance in industry sector at the $10^{\text {th }}$ time horizon, thus industrial sector is strongly affected by agriculture sector, and the long run causality runs from agriculture sector to industrial sector. 41 percent variance in service sector explained at the $10^{\text {th }}$ time horizon is explained by Industrial sector, thus causality looks to run from industry sector to service sector. However, the predominance of service sector over industrial sector in under developed economy is not preferable, at least at early stage of development. Hence, the results of both Impulse response and Variance decomposition identify that agricultural sector as the major economic activity that controls and affects most of economic activities in Ethiopia. The sector has a dynamic effect on industrial sector. From our descriptive analysis part the share of agricultural sector has been declining significantly over the study period. The sector covered $66 \%$ of GDP in 1975 which has declined to $36 \%$ in 2017 . Moreover most of the variation in growth rate of GDP comes from agricultural sector. This shows that how the economy depends on agricultural sector. Therefore, the declining percentage share of agricultural sector to GDP doesn't exhibit the true structural transformation. The analysis of intersectoral linkages identified agricultural sector as the core economic activity that controls most economic activities in Ethiopia.

\subsection{Recommendations}

From the study result we have found that agricultural and service sectors are exogenous and industrial sector as endogenous to the system. Hence as long as industrialization is a big concern of sustainable and lasting development, policies that increase the linkage between agricultural and industrial sectors are preferable. In this regard structural polices like ADLI, if correctly implemented, will have not only a transformational upshot but also a sustainable growth effect, as agricultural sector affects the industry through its causality linkage. The existence of uni-directional causality between agricultural and industrial sector in Ethiopia provides a support for the need of increasing resources to agricultural research, rural and infrastructural development. A developing country like Ethiopia which is food insecure, its economic growth could be driven by policies that promote agriculture. The weak linkage between agricultural and service sectors can be related directly to the problems of fragile power supply, inadequate infrastructure, poor marketing chain, low road network, logistic and etc. The nature of such weak intersectoral relationships possibly indicates that at least any policy priority supporting services sector need not necessarily go against agricultural sector since the services sector causes agricultural sector at least in the short run.

From standard point of view, in the initial stages of economic development, most of the economic resources are allocated to the agricultural sector; but as the economy progresses, resources are reallocated from agriculture to industrial and service sectors; as the economy develops further, resources are again transferred from both agricultural and industrial sectors to service sector. Hence industrialization should come after agricultural transformation achieved. Therefore, the government of Ethiopia should enhance the agricultural sector through, mechanization, land defragmentation, irrigation, modern input supply...etc. that could boost the sector. The declining agricultural share of GDP doesn't merely indicate the existence structural transformation and the sector is still the pillar of the economy as confirmed by causality analysis. Moreover, the three sectors are interlinked with each other; any changes of policy strategy in one sector will automatically affect the other sectors and the economy in general. Therefore government or policy makers should implement policies bearing in mind the linkages and direction of causality among sectors of the economy.

\section{References}

[1] Alemu Z G, K. O. (2003). Contribution of agriculture in the Ethiopian economy: a time-varying parameter approach. Agrekon, 42, 29-48.

[2] Banumathy, K., \& Azhagaiah, R. (2015). Long-Run and Short-Run Causality between Stock Price and Gold Price: Evidence of VECM Analysis from India. Management Studies and Economic Systems (MSES), 247-256.

[3] Bathla, S. (2003). Inter-sectoral growth linkages in India: implications for policy and liberalized reforms. India.

[4] Berhanu, N. (1996). Development Options for Ethiopia: Rural, Urban or Balanced.

[5] Chebbi, H. E. (2010). Agriculture and economic growth in Tunisia. China agricultural Economic review, 2 (1), 63-78.

[6] Engle, R., \& Granger, C. W. (1987). Co-Integration and Error Correction: Representation, Estimation, and Testing. Econometrica, 55 (2), 251-276.

[7] Erjavec, N., \& Cota, B. (2003). Macroeconomic grangercausal dynamics in Croatia: evidence based on a vector errorcorrection modeling analysis. Ekonomski pregled, 54 (1-2), 139-156.

[8] Fantu, C. (2016). Structural Transformation in Ethiopia: The Urban Dimension. ECPI Discussion Paper Final Stockholm International Peace Research Institute. 
[9] Fasikaw A. (2018). An Empirical Investigation of Inter Sectoral Linkage in Ethiopia: A Co-Integrated VECM Approach, June, 2018 Addis Ababa university, Ethiopia. Unpublished thesis paper.

[10] Geda, A., Zerfu, D., \& Ndung'u, N. (2011). Applied TimeSeries Econometrics: A Practical guide for Macroeconomic Researchers with a focus on Africa. Central Bank of Kenya, African Economic Research Consortium and Addis Ababa University.

[11] Gunjeet Kaur, S. B. (2009). An empirical investigation on their inter-sectoral linkages in India. Reserve Bank of India Occasional Papers, 30-72.

[12] Hirota, Y. (2002). Reconsidering of the Lewis Model: Growth in a Dual Economy.

[13] James F Oehmke, A. N. (2016). James F Oehmke, Anwar Naseem, Jock Anderson, Carl Pray, Contemporary African Structural transformation: An Empirical Assessment.

[14] João, G., Gilson, P., \& Marta C. N., S. (2014). Agriculture in Portugal: linkages with industry and services.

[15] Johansen, S. (1992). Testing Weak Exogeneity and the Order of Cointegration in UK Money Demand. Journal of Policy Modeling, 313-334.

[16] Johansen. (1988). Statistical analysis of co-integrating vectors. Journal of Economic dynamic and control, 12, 231-255.

[17] Kassahun, T. (2006). Dynamic Sectoral Linkages in the Ethiopian Economy: A preliminary Assessment. Addis Ababa: Ethiopian Economic Association/Ethiopian Economic Policy Research Institute.

[18] Katircioglu, S. (n. d). Co-Integration and Causality between GDP, Agriculture, Industry and Services growth in North Cyprus: Evidence from Time Series Data, 1977-2002. Review of Social, Economic \& Business Studies, 7/8, 173-187.

[19] Kaur, G., Bordoloi, S., \& Rajesh, R. (2009). An empirical investigation on the inter-sectoral linkages in India. Reserve Bank of India.

[20] Kelikume, D. S. (2011). Empirical analysis of the linkages between the manufacturing and other sectors of the Nigerian economy. 150.

[21] Kohansal, M. T. (2013). Agricultural impact on economic growth in Iran using ARDL approach to co-integration. International Journal of Agriculture and Crop Sciences, 12231226.

[22] Kym, A. (1987). On Why Agriculture Declines with Economic Growth.

[23] Matahir, H. (2012). The empirical investigation of the nexus between agricultural and industrial sector in Malaysia. International Journal of Business and Social Science, 225-231.

[24] MoFED. (2010). Growth and Transformation Plan (GTP I) 2010/11-2014/15. Addis Ababa: Ministry of Finance and Economic Development.

[25] Naval, M. R. (2016). An Empirical study of Inter-Sectoral Linkages and Economic growth in India. American Journal of Rural Development, 4, 78-84.

[26] NPC. (2016). Growth and Transformation Plan II (2015/162019/20). Addis Ababa: National Planning Commission.
[27] Perez, K. K. (2004). Unbalanced growth. National bureau of economic research. NBER working paper series.

[28] Phillips, P. a. (1988). Testing for a Unit root in time series regression. Biometrika,, 335-346.

[29] Rahel, K. (2003). Ethiopia's recent growth performance: a Survey of the literature.

[30] Roman, T. (2012). The link between financial development and economic growth in Ethiopia. Addis Ababa, Ethiopia: Unpublished thesis paper.

[31] Saikia, D. (2011). Analyzing inter-sectoral linkages in India. African Journal of Agricultural Research, 6 (33), 6766-6775.

[32] Seid, N. (2015). Prospects and Challenges of Structural Transformation in Ethiopia: Assessing the Performance of GTP I and Reflecting on GTP II. Addis Ababa. Ethiopian Economics Association Ethiopian Economic Policy Research Institute.

[33] Sepehrdoust, H., \& Adnan, Q. m. (2012). An empirical study of inter-sectoral linkages and Economic growth. Academic Journals Inc., 494-504.

[34] Sikhosana N, T. A. (2015). Inter-sectoral linkages and Agricultural growth in Swaziland for the period 1971-2011. Journal of Economics and Sustainable Development, 6, 218228.

[35] Subramaniam, V. (2010). Agricultural intersectoral linkages and their contribution to economic development.

[36] Sylvester, A. A., Benedict, U. A., \& Effifiom, E. C. (2016). Analysis of the Sectoral Linkages and Growth Prospects in the Nigerian Economy. IOSR Journal of Economics and Finance (IOSR-JEF), 7 (6), 73-80.

[37] Tadele, F. (2000, April). Measuring sectoral interdependence in Ethiopia: a social accounting matrix (SAM) approach. Ethiopian Journal of Economics, IX.

[38] Tadele, F. (2015). Sectoral economic growth and structural transformation in Ethiopia. Department of Economics, Addis Ababa University.

[39] Timmer p., M. M. (2012). Patterns of growth and structural transformation in Africa: trends and lessons for future development strategy. International Food Policy Research Institute.

[40] Uddin, M. M. (2015). Causal Relationship between Agriculture, Industry and Services Sector for GDP Growth in Bangladesh: An Econometric Investigation. Journal of Poverty, Investment and Development, 18, 124-130.

[41] UN-Habitat. (n. d). Structural transformation in developing countries: Cross regional analysis. Nairobi, Kenya.: Structural transformation in developing co United Nations Human Settlements Programme (UN-Habitat).

[42] Verner, N. M. (2001). Inter-sectoral dynamics and economic growth in Ecuador. The World Bank Latin America and the Caribbean Region Economic Policy Sector Unit.

[43] Wooldridge, M. (2000). Introductory Econometrics: A Modern Approach (2 ed.).

[44] Worku Gebeyehu, G. A. (2013). Which Sector Should Lead In Ethiopia? Industry or Agriculture? Addis Ababa: Ethiopian Economic Association. 
[45] Wubshet, O. (2008). The determinant of aggregate import demand in Ethiopia: co integration analysis. Addis Ababa, Ethiopia. unpublished thesis.

[46] Xinshen, D. \& Steven Haggblade, B. F. (2007). Agricultural Growth Linkages in Ethiopia: Estimates using Fixed and Flexible Price Models. Washington: international food policy.
[47] https://tradingeconomics.com/ethiopia/gdp-growth-annual 2018.

[48] USAID/Ethiopia Agriculture Knowledge, Learning, Documentation and Policy Project. 